\title{
Long-term emissions from mechanically biologically treated waste: Influence on leachate quality
}

\author{
Mark Griffith and Cristina Trois* \\ CRECHE (Centre for Research in Environmental, Coastal and Hydrological Engineering), School of Civil Engineering, \\ Surveying and Construction, University of KwaZulu-Natal, 4041 Durban, South Africa
}

\begin{abstract}
Long-term emissions from municipal solid waste landfills can be reduced by mechanical-biological treatment (MBT) of waste prior to disposal. The pretreatment accelerates waste degradation resulting in a reduction of the landfill's polluting potential. This study reports on the applicability and efficiency of MBT in Durban, South Africa. Waste treatment in passively aerated open windrows, using the Dome Aeration Technology (DAT), was identified as an appropriate technology due to low construction and operational resource requirements. Three self-aerated windrows were set up at the Bisasar Road Landfill in order to study the efficiency of the process for different composting timeframes ( 8 and 20 weeks). The 'post-landfilled' behaviour of the pretreated material was analysed in anaerobic lysimeters. The effect of different degrees of degradation was studied in relation to waste composition and rate of irrigation. The lysimeter tests demonstrated that the initial acidic inhibition that is characteristic of waste with high organic content can be eliminated through pretreatment. Notwithstanding the rapid onset of methanogenesis, high COD concentrations of non-degradable organics in the leachate remain after $200 \mathrm{~d}$ of testing. Despite the high COD levels, a clear benefit of waste pretreatment is the low concentration of ammoniacal nitrogen after only 8 weeks of composting. The results of this research can be used to define a framework for sustainable waste disposal, particularly in relation to the subtropical climatic conditions experienced in Durban, resource availability and waste composition.
\end{abstract}

Keywords: mechanical-biological treatment (MBT), landfills, MSW, leachate

\section{Introduction}

As a developing country, South Africa faces the challenge of meeting international standards in service delivery. Waste disposal, in particular, must be environmentally acceptable and economically sustainable. Currently, $95 \%$ of waste is disposed in landfills (DWAF, 1998a). It is well accepted that landfilling of large quantities of degradable organic material in a complex and heterogenic anaerobic environment, such as a landfill, will result in the formation of an inefficient biological reactor with the potential to produce persistent liquid and gaseous emissions. The significance of this problem has been recognised by the Department of Water Affairs and Forestry (DWAF) and the introduction of the Minimum Requirements for Waste Disposal by Landfill in 1994 was a crucial step in implementing more stringent landfill engineering guidelines to curtail long-term environmental impacts. The aim of the Minimum Requirements is to control landfill emissions through the "concentrate and contain' approach, where the landfill is designed and operated as a multi-barrier system (DWAF, 1998a) in areas where significant leachate generation is expected, such as Durban. It must be remembered that in some of the drier regions of the country, leachate generation is sporadic or negligible (DWAF, 1998a).

A significant aspect of landfill management is the 'aftercare' period when, after closure, control of landfill emissions is still required. The reduction of pollution levels from landfills is dependent on the stabilisation of the degradable organic fraction in the waste and the removal of the soluble pollutants through

\footnotetext{
* To whom all correspondence should be addressed.

诲 +27312603065 ; fax: +2731 2601411 ;

e-mail:troisc@ukzn.ac.za

Received 16 January 2006; accepted in revised form 10 March 2006.
}

a combination of biochemical reactions and physical leaching. These processes are directly related to the flux of moisture through the waste body; the very same process that current South African legislation aims at reducing. The multi-barrier landfill, may, therefore, constitute an efficient short-term solution but can prolong the long-term pollution risk indefinitely. This fundamental truth on the nature of modern landfills is well accepted by the scientific community (Robinson, 2000; Cossu et al., 2003). In Europe the focus has now shifted towards the stabilisation of waste prior to landfilling via thermal (incineration) or mechanical biological treatment (Stegmann, 2005). The European Council Landfill Directives 1999/31/EEC (LFD) require member states to only landfill wastes that have been subjected to prior treatment (Robinson et al., 2005a).

A comparative study of available waste pretreatment techniques was initiated in 2002 (Griffith, 2005) to identify suitable solutions for South Africa that could be implemented at national level into established waste management systems (municipal disposal units) as well as informal/rural communities. Factors such as low operational costs, zero/low energy input during the composting period, potential for labour-intensive operations and reduced machinery requirements were considered in the selection of appropriate technologies. The results of the study pointed to the dome aeration technology (DAT) treatment in passively aerated windrows as a suitable option (Paar, 1999a; b; Mollekopf et al., 2002; Trois and Polster, 2006). Experience in Germany has shown that 'chimney' technology can achieve $90 \%$ reduction of landfill emissions, making it an appropriate technique for countries where pretreatment is still not a minimum requirement (Münnich et al., 2006).

A pilot project was designed to study the applicability of aerobic waste composting to the South African waste management context and prevailing subtropical conditions. This paper 
Figure 1 (top right)

The thermally driven aeration process of the DAT windrows

Figure 2 (middle right)

Schematic plan view of typical DAT windrow

Figure 3 (bottom right)

A completed DAT windrow during the early intensive degradation stage

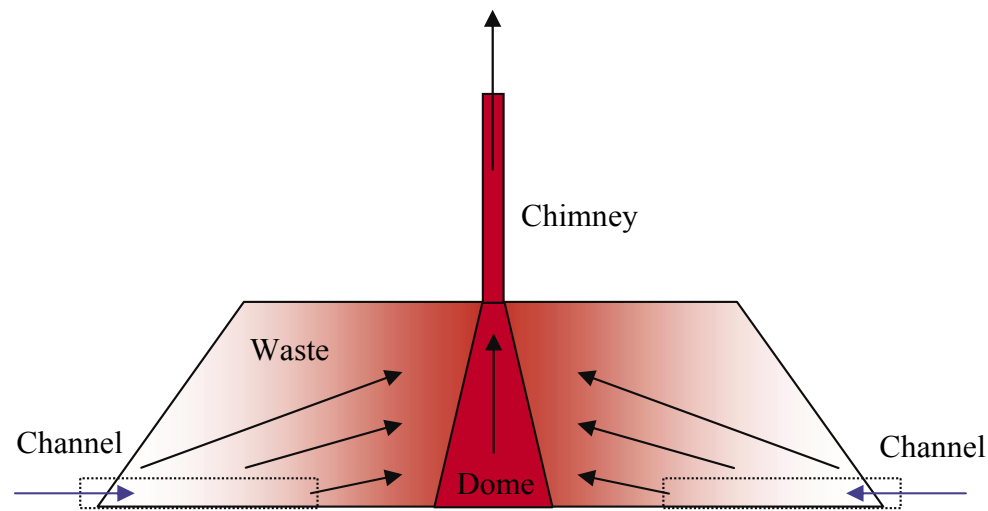

describes the operational techniques adopted and focuses on the results of an investigation on the long-term impacts of the treated waste in anaerobic reactors (lysimeters) in relation to waste composition and rate of flushing. The pilot project of waste treatment and the lysimeter studies conducted in Durban are described in this paper.

\section{Principles of the dome aeration tech- nology (DAT)}

Mechanical-biological treatment (MBT) is a twostage process, involving the mechanical preparation of the waste, followed by biological composting. The mechanical treatment

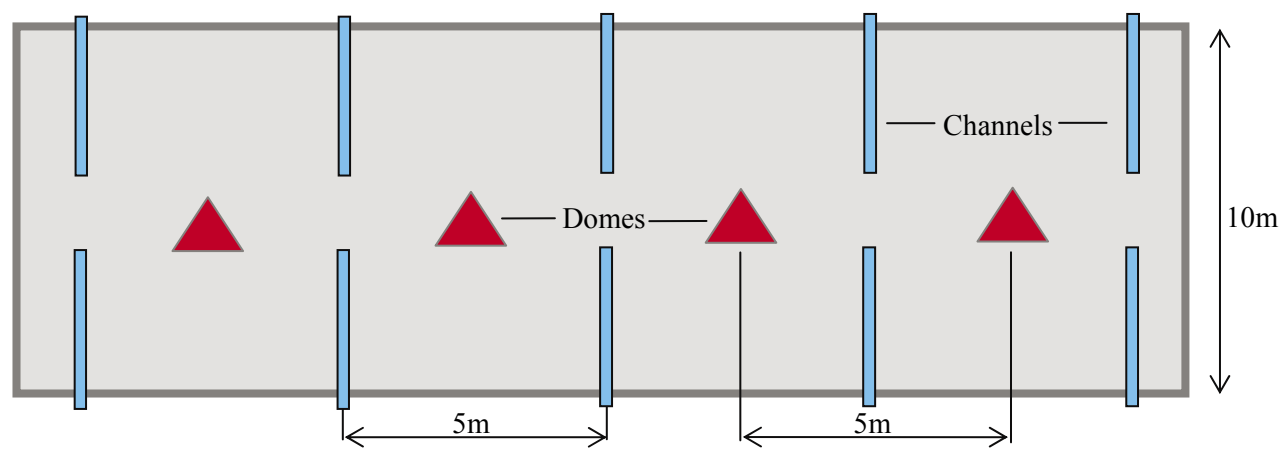
step removes useful frac-

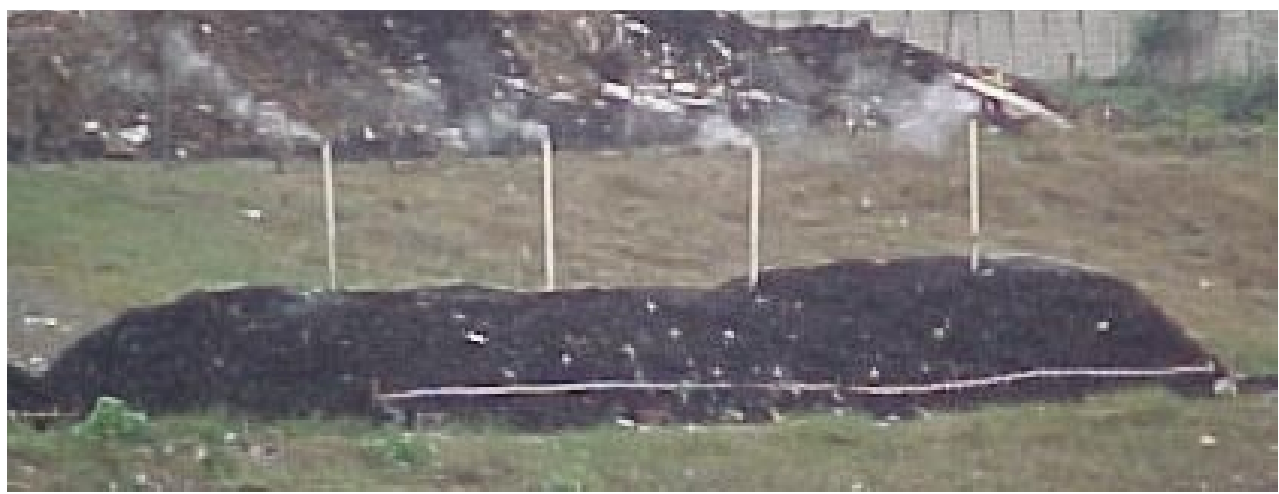

tions and prepares the biodegradable portion for optimal microbial activity. The process includes sorting, shredding/homogenisation and adjustment of moisture content. The most commonly implemented biological treatment stage is thermophilic aerobic composting in open systems or closed reactors (Soyez and Plickert, 2002). Composting reactors are closed vessels that utilise mixing or a forced air supply to ensure aeration. The advantage of these systems is their high efficiency and control over odour and leachate, although their complexity makes this technology expensive (Münnich et al., 2006). Open systems or non-reactor systems use windrows of waste which are aerated either by turning, through forced aeration or by natural thermal convection (passive aeration). The open composting systems are generally more cost-effective; however, there is less control over the process and thus degradation and emission control are less efficient than in reactor systems (Haug, 1993; Stegmann, 2005).

DAT is a passive aeration system that utilises thermal advection caused by temperature differences between the degrading material and the outside environment to drive the aeration process within a windrow of waste (Mollekopf et al., 2002). Steel mesh structures with a PVC chimney (called domes) which are placed in the centre of the windrow create a large air vent for hot gases flowing out of the system, and colder ambient air is drawn into the waste through lateral base channels (Fig. 1). Domes and channels are arranged in a staggered layout in order to maximise the distribution of air through the waste (Fig. 2). A completed windrow is shown in Fig. 3.

A high porosity of the waste is required for effective air-flow and is achieved by mixing the general waste with a more rigid structural material (SM) generally comprised of woody waste and dry branches from garden refuse. The site operations entail a three-step mechanical pretreatment stage of mixing, crushing and wetting, followed by composting for three to four months (Paar et al., 1999a; b, Mollekopf et al., 2002; Trois et al., 2005; Trois and Polster, 2006). After the composting is complete the material passes through a 60 to $100 \mathrm{~mm}$ screen. The fine fraction may be used as cover material for other windrows while the rest is landfilled.

\section{Application of DAT in South Africa: Durban case study}

Three full-scale DAT windrows were constructed at the Bisasar Road Landfill site and monitored for 20 weeks. Size and layout 


\begin{tabular}{|l|l|l|l|}
\hline \multicolumn{4}{|c|}{ Summary of the construction parameters for the Durban trials } \\
\hline & Windrow 1 & Windrow 2 & Windrow 3 \\
\hline Waste input (Ratio) & $\begin{array}{l}50 \% \text { Solid waste, structural } \\
\text { waste (1:1) 50\% pine bark }\end{array}$ & $\begin{array}{l}\text { Solid waste, structural waste, } \\
\text { pine bark (2:1:1) }\end{array}$ & $\begin{array}{l}\text { Solid waste, structural waste, pine } \\
\text { bark (2:1:1) }\end{array}$ \\
\hline Machinery usage & $\begin{array}{l}\text { Landfill compactor, front end } \\
\text { loader, water truck, excavator }\end{array}$ & ADT, water truck, excavator & $\begin{array}{l}\text { Front-end loader, ADT, water } \\
\text { truck, excavator }\end{array}$ \\
\hline Number of domes & $\begin{array}{l}\text { 3 Domes waste } \\
3 \text { Domes bark }\end{array}$ & 3 Domes of waste & 4 Domes of waste \\
\hline Windrow size & $\begin{array}{l}325 \mathrm{~m}^{3} \text { waste } \\
325 \mathrm{~m}^{3} \text { bark }\end{array}$ & $350 \mathrm{~m}^{3}$ & $450 \mathrm{~m}^{3}$ \\
\hline Time required to construct & $20 \mathrm{~h}$ & $20 \mathrm{~h}$ & $12 \mathrm{~h}$ \\
\hline
\end{tabular}

of the windrows were modified from the German experience to take into account the influence of local climatic conditions, different nature and composition of the waste, available construction and operational facilities. Samples of waste were collected before treatment and after 8 and 20 weeks of treatment for characterisation and for input into the lysimeters.

\section{Climatic conditions}

Since the DAT flow mechanisms rely on the thermal gradient between the ambient air and the gas generated within the windrow, it was assumed that higher ambient temperatures could reduce the aeration rates. Durban's climate is typically subtropical: warm and humid with a mean annual temperature of $20.5^{\circ} \mathrm{C}$ and average annual precipitation around $1000 \mathrm{~mm}$ (concentrated between October and April). Daily minimum temperature averages between $21^{\circ} \mathrm{C}$ in summer and $10^{\circ} \mathrm{C}$ in winter. Maximum temperatures, on the other hand, average around $17^{\circ} \mathrm{C}$ and $30^{\circ} \mathrm{C}$ in winter and summer, respectively. The relative humidity is very high and often exceeds $70 \%$ in the summer. As the system is reliant on the thermal gradient between the windrow and the ambient air, concerns were raised over the effect of the higher temperatures experienced in Durban when compared to Germany. As a result, a conservative approach was adopted, so that the Durban windrows were reduced in size to $30 \mathrm{~m}$ long, $10 \mathrm{~m}$ wide and $2.5 \mathrm{~m}$ high (20\% smaller than the German windrows (Trois et al, 2005)) as a smaller windrow would require less efficient aeration. In order to cover the entire seasonal spectrum the $1^{\text {st }}$ windrow was constructed in June, the $2^{\text {nd }}$ in December and the $3^{\text {rd }}$ in April.

\section{Construction and operation of the windrows}

Construction and operation techniques adopted for the Durban trials were based on the experience of the Cottbus Landfill in Germany, where post-treatment of residues from high-tech MBT (with refractory-organic fine fraction remaining) is achieved to EU standards in only 3 to 4 months, with no turning (Mollekopf et al., 2002). The material received at general waste landfills in Durban is primarily constituted by $46 \%$ municipal solid waste, $40 \%$ inert material, $7 \%$ builders rubble and $7 \%$ garden refuse by mass (Bisasar Rd weighbridge data 2002-2005 - source Durban Solid Waste). The large percentage of inert material and builders' rubble is used for daily cover for the waste as stipulated by DWAF (1998). Approximately two thirds of the municipal solid waste (MSW) is degradable (putrescibles, paper and cardboard) while the remainder comprises plastics, glass and metals (DMWS, 1998). MSW from Rotor-press trucks was used as the rotary compaction shredded the waste.
It must be noted that there is no separate collection conducted apart from garden refuse which is also disposed of at MSW landfill sites in a different waste stream. In this investigation pine bark was also used to supplement the SM and as biofilter cover material to maintain the initial moisture content at optimal levels (55 to $65 \%$ ) throughout the duration of the treatment. A summary of the windrow construction parameters is presented in Table 1.

Maximum temperatures reached indicate that $70^{\circ} \mathrm{C}$ is the upper limit for thermophilic composting using DAT. However, a problem was encountered in Windrow 2 where the biological activity was drastically reduced due to desiccation of the waste. Total $\mathrm{CO}_{2}$ production indicated that Windrow 2 was biologically active for an effective time of only 2 to 8 weeks, although the target period was 20 weeks of composting. Thus, although studies were conducted on this waste, it was considered to be unrepresentative of 20 weeks pretreated waste and so the results are not presented herein. Windrow 3 remained biologically active for the entire composting time and the pretreatment was considered to be a success. A more detailed description of the windrow trials and results of the process monitoring phase are presented in Trois et al. (2005).

Laboratory tests in anaerobic reactors were carried out to simulate the long-term behaviour of the treated waste once landfilled. Three insulated $1000 \ell$ low density polyethylene tanks were installed with a leachate recirculation system consisting of a stone drainage layer, a pump, sprinkler and two sampling points - one at the base and one in the centre of the waste. Waste temperature and biogas measurements were conducted weekly through sampling points at the top of the tank. Each lysimeter was filled with approximately $500 \ell$ of un-compacted waste as follows: Lysimeter 1 with fresh (un-composted) waste from construction of the third windrow (control reactor) and Lysimeter 2 with 8 weeks pretreated waste from a section of the third windrow. The input material to the lysimeters was characterised using eluate/leaching tests on coarsely shredded waste samples. After $24 \mathrm{~h}$ leaching (TS to liquid ratio of 1:10) the eluates were coarsely filtered (Filter paper type Whatmann 40) and tested

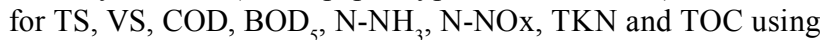
standard procedures (ASTM, 2004). Moisture content, total and volatile solids were determined on the solid matter (ASTM, 2004). The waste was weighed before placement in the lysimeters and the moisture content raised to field capacity (Table 2). Field capacity is the moisture content at which waste no longer retains additional water, a requirement if liquid samples were to be extracted. Note that only average values of minimum five repetitions are reported in Table 2; accuracy checks conducted weekly on the measurements confirm that the overall error was maintained at between 5 to $10 \%$. 


\begin{tabular}{|c|c|c|c|c|}
\hline \multicolumn{5}{|c|}{$\begin{array}{c}\text { TABLE } 2 \\
\begin{array}{c}\text { Characterisation of the input material } \\
\text { to the lysimeters }\end{array}\end{array}$} \\
\hline Parameter & Unit & $\begin{array}{c}\text { Un- } \\
\text { treated } \\
\text { waste }\end{array}$ & $\begin{array}{c}8 \\
\text { Weeks } \\
\text { MBT }\end{array}$ & $\begin{array}{c}\text { EU } \\
\text { require- } \\
\text { ments }\end{array}$ \\
\hline \multicolumn{5}{|c|}{ Solids test results } \\
\hline Moisture content & $\%$ Total mass & 49 & 38 & - \\
\hline Volatile solids & $\%$ Dry mass & 70 & 44 & - \\
\hline Field capacity & $\%$ Total mass & 59 & 54 & - \\
\hline \multicolumn{5}{|c|}{ Eluate test results } \\
\hline $\mathrm{pH}$ & & 7.05 & 6.83 & $5.5-13.0$ \\
\hline COD & $\mathrm{mg} / \ell$ & 13090 & 2850 & - \\
\hline $\mathrm{BOD}_{5}$ & $\mathrm{mg} / \ell$ & 2272 & 443 & - \\
\hline $\mathrm{N}-\mathrm{NH}_{4}$ & $\mathrm{mg} / \ell$ & 60.17 & 13.56 & $<200$ \\
\hline $\mathrm{N}-\mathrm{NOx}$ & $\mathrm{mg} / \ell$ & 50.8 & 5.44 & - \\
\hline TOC & $\mathrm{mg} / \ell$ & 3181 & 831 & $<250$ \\
\hline
\end{tabular}

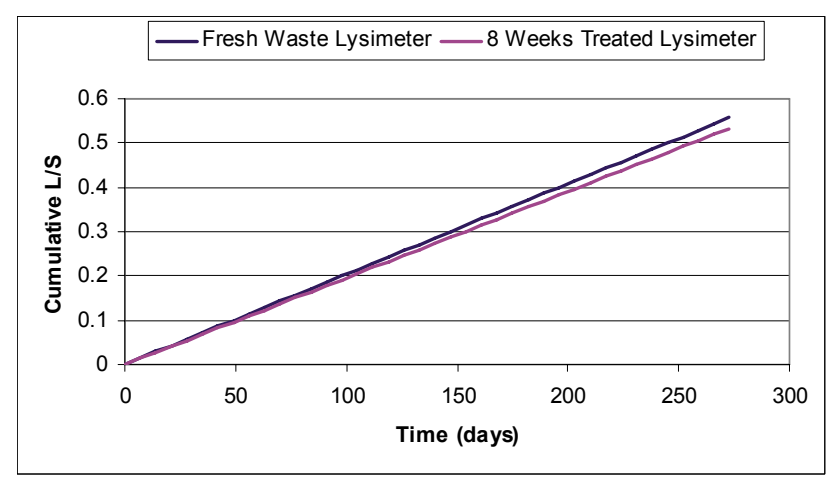

Figure 4

Evolution of $L / S$ for both lysimeters with time

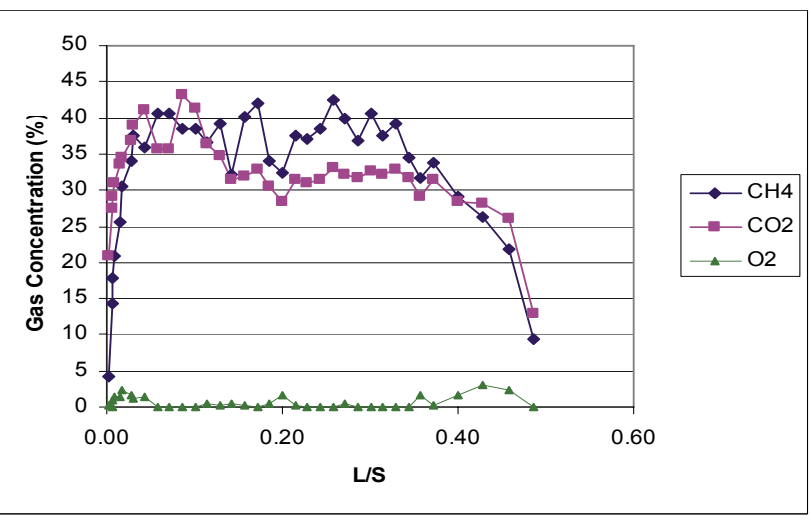

Figure 5

Biogas concentrations in Lysimeter 1

\section{Results and discussion}

\section{Lysimeter 1: Fresh untreated waste}

to standard methods (ASTM, 2004) for the following parameters: Conductivity, $\mathrm{pH}$, alkalinity, $\mathrm{BOD}_{5}, \mathrm{COD}, \mathrm{N}-\mathrm{NH}_{3}, \mathrm{TKN}$, $\mathrm{N}-\mathrm{NOx}$. Levels of $\mathrm{CH}_{4}, \mathrm{CO}_{2}$ and $\mathrm{O}_{2}(\%$ by volume $)$ were measured weekly using an infrared gas analyser (Model GA94) together with internal temperature readings using a thermocouple.

Due to the slowing down of biological activity over time, the release of pollutants from a landfill site in the long term is primarily reliant on physical leaching. The degree of leaching for a particular body of waste is described using the liquid to solid ratio (L/S) which represents the volume of water that has passed through the landfill body and is expressed as volume per unit mass of waste (dry mass). The assumption is that in the long term the physical leaching is not time dependent, but rather reliant on the flux of water through the waste. This allows for a direct comparison with full-scale landfill sites (Leikam et al., 1997; Kylefors et al, 2003; Robinson et al., 2005b). The testing period extended for $273 \mathrm{~d}$ and, based on a weekly extraction of $2.5 \ell$, resulted in a cumulative $\mathrm{L} / \mathrm{S}$ ratio of 0.55 . This represents approximately 30 years of infiltration for a landfill $20 \mathrm{~m}$ deep with a dry density of $600 \mathrm{~kg} / \mathrm{m}^{3}$ and an annual infiltration rate of $250 \mathrm{\ell} / \mathrm{m}^{2} \cdot \mathrm{a}$ (Leikam et al., 1997). The $250 \mathrm{\ell} / \mathrm{m}^{2}$ is a generalised figure as the landfill water balance is site-specific (infiltration at the Bisasar Road Landfill site is approximately $170 \mathrm{\ell} / \mathrm{m}^{2} \cdot \mathrm{a}$ ). This is based on the assumption that the waste is at field capacity and the leachate released is equivalent to the annual infiltration. The results for significant leachate quality parameters are presented below in relation to the cumulative $\mathrm{L} / \mathrm{S}$ ratio used in this investigation. The evolution of $\mathrm{L} / \mathrm{S}$ with time is presented in Fig. 4.
Biogas emissions from Lysimeter 1 are shown in Fig. 5. The methane concentration increased to 40 to $45 \%$ immediately after commencement of the trials. This rapid increase indicates that there was a limited acidic inhibition during the early stages of degradation. The period after the onset of methanogenesis is generally the stage of peak biological activity (Robinson, 1989). Although biogas volumes were not measured, the decrease in biogas concentrations towards the end of the test is indicative of slower production kinetics as ambient air begins to diffuse into the lysimeters headspace back through the biogas vent. This is evident in the increase of nitrogen gas concentration (not shown here), which accounts for the balance of the gasses in the lysimeters. The oxygen levels remain low due to consumption by facultative anaerobic and aerobic micro-organisms in the upper layers.

Figure 6 shows the evolution of COD and $\mathrm{pH}$ in the leachate from Lysimeter 1. Following an initial increase to $5500 \mathrm{mg} / \ell$, the organic content in the leachate falls to steady levels of approximately $600 \mathrm{mg} / \ell$. The BOD to COD ratio at the final stages of the study was 0.4 indicating that a relatively large proportion of degradable organics was still present. At an $\mathrm{L} / \mathrm{S}=0.2$ (after $100 \mathrm{~d}$ ), the leachate is typical of a methanogenic state, with low COD concentrations and a neutral $\mathrm{pH}$. The rapid decrease in as the intermediate products of anaerobic digestion are converted into methane and carbon dioxide. COD is indicative of the activity of the methanogenic bacteria, 


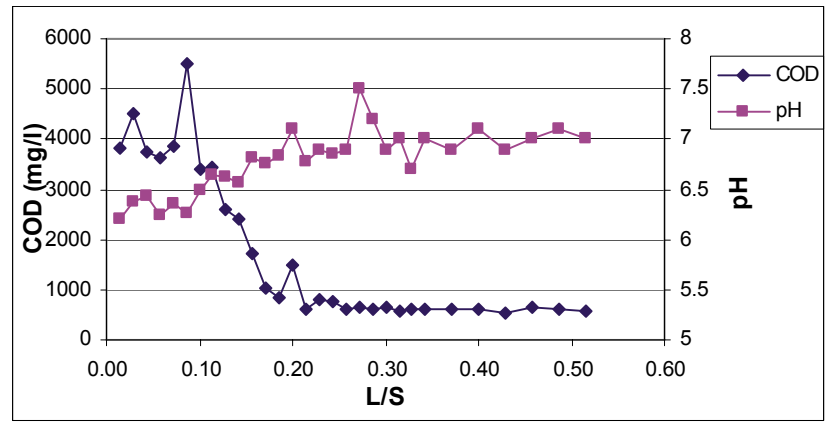

Figure 6

Evolution of $\mathrm{pH}$ and $\mathrm{COD}$ in the leachate from Lysimeter 1

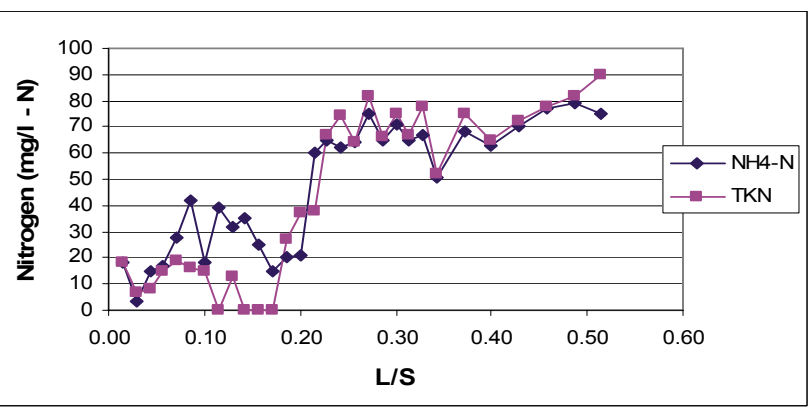

Figure 7

Evolution of $\mathrm{NH}_{4}-\mathrm{N}$ and TKN in the leachate from Lysimeter 1

The evolution of the nitrogen compounds is shown in Fig. 7. The total Kjeldahl nitrogen (TKN) rises steadily as proteinaceous molecules are broken down by the microbial activity and nitrogenous compounds released into the leachate. The majority of the TKN is in the form of ammoniacal nitrogen which reaches steady levels of approximately $80 \mathrm{mg} / \ell$ at the end of the analysis period. Nitrates and nitrites were detected in negligible concentrations (generally $<0.1 \mathrm{mg} / \ell$ ) indicating that any aerobic activity within the lysimeter was insignificant. An unusual occurrence was the measurement of TKN levels lower than that of the ammoniacal nitrogen. Such readings, also reported by Bone et al. (2003) are physically impossible as TKN is the sum of ammoniacal and organic nitrogen and cannot be explained.

The COD and $\mathrm{NH}_{4}-\mathrm{N}$ did not reach high levels as in other investigations (Novella et al., 2001). Furthermore, there was a negligible acidic inhibition evident in the early stages of the degradation process, as was found in other studies on untreated waste (Novella et al., 1997; Leikam et al., 1997; Cossu et al., 2003). This may be attributed to the large proportion of slowly degradable structural material (woody waste and pine bark) present in the lysimeter. The decrease in biogas $\left(\mathrm{CH}_{4}\right.$ and $\left.\mathrm{CO}_{2}\right)$ concentrations coupled with the stabilisation of ammonia-nitrogen levels indicates that the rate of biological activity slowed towards the end of the trials. However, the relatively high BOD to COD ratio (0.4) suggests that a significant portion of the leachate was organic and that biodegradation was still taking place as a result of the slowly degradable fractions (BOD: COD ratios of 0.7 or greater are found in organic rich leachates (Robinson, 1989) while ratios of less than 0.1 are expected for leachates from highly degraded waste (Robinson et al., 2005).

\section{Lysimeter 2: 8 weeks treated waste}

Biogas emissions from Lysimeter 1 are shown in Fig. 8. The biogas readings show a rapid increase in $\mathrm{CO}_{2}$ levels as residual

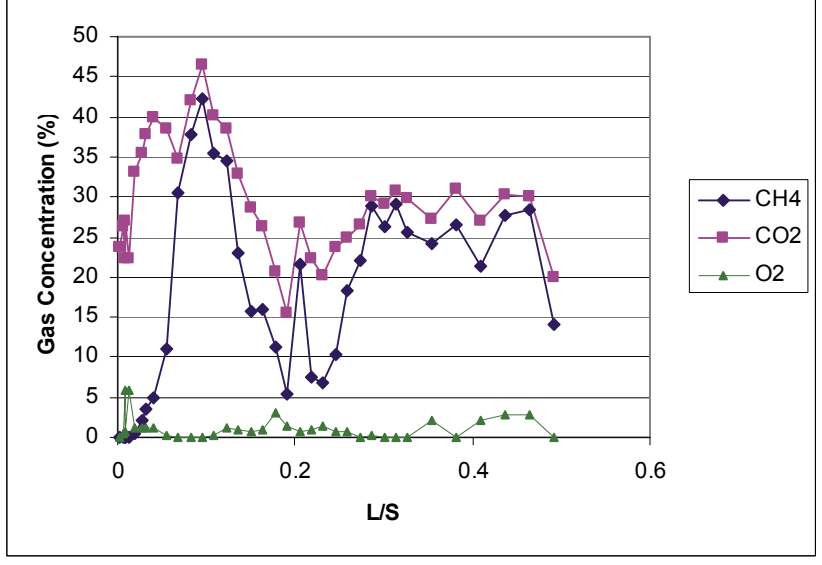

Figure 8

Biogas concentrations in Lysimeter 2

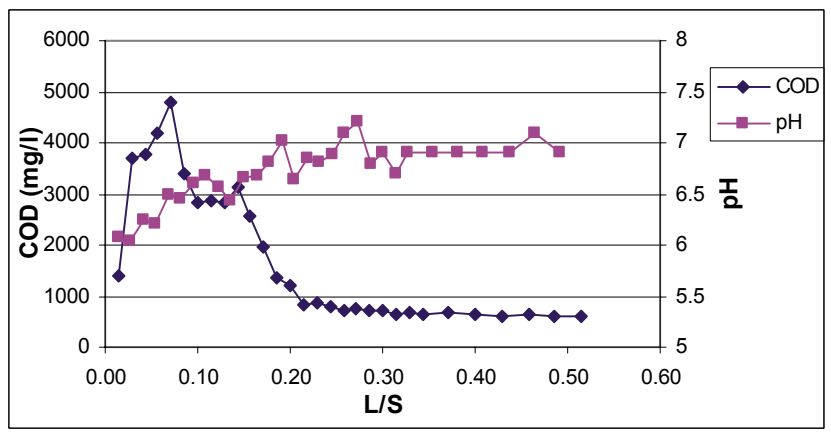

Figure 9

Evolution of $\mathrm{pH}$ and $\mathrm{COD}$ in the leachate from Lysimeter 2

atmospheric oxygen is consumed by aerobic bacteria. After the oxygen has been exhausted the methanogenic bacteria become established. It must be noted that the biogas concentration readings were affected by a break in the seal of the lysimeter lid. Once the broken seal had been discovered, the lid was resealed and the gas levels returned to expected levels.

A typical pattern of anaerobic degradation is evident in Fig. 9, with an early peak of COD which then decreases as the methanogenic bacteria become established. There is no acidic inhibition of the methanogenic activity, although the biodegradation kinetics are slow at the start of the test (shown by the slow uptake of oxygen) indicating low quantities of readily degradable organic compounds. Methanogenesis is achieved at $\mathrm{L} / \mathrm{S}=$ 0.2 (after $100 \mathrm{~d}$ ) indicated by the significant drop decrease in COD levels and a neutral $\mathrm{pH}$. The drop in biogas concentrations towards the end of the testing indicates a decrease in biological activity. The methanogenic COD levels remain steady at approximately $600 \mathrm{mg} / \ell$ with a COD: BOD ratio of 0.4 . As for Lysimeter 1, this indicates that a significant proportion of degradable organics were still present in the leachate at the end of the test period.

The TKN, most of which is in the form of ammoniacal nitrogen, increases steadily to $22 \mathrm{mg} / \ell$ (Fig. 10). The ammoniacal nitrogen concentration at the end of the test was $16 \mathrm{mg} / \ell-$ far lower than that of the raw waste in Lysimeter 1 . These low levels of ammoniacal nitrogen are a feature of aerobically pretreated wastes (Robinson et al., 2005). As with Lysimeter 1, the TKN was at times measured to be lower than that of the ammoniacal nitrogen. 


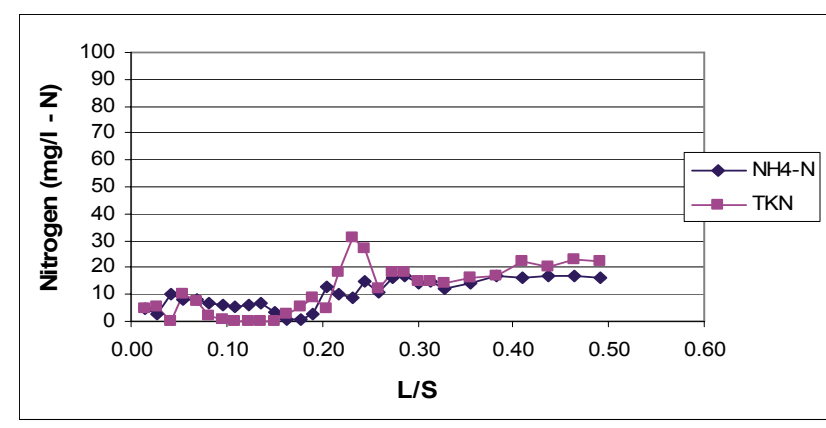

Figure 10

Evolution of $\mathrm{NH}_{4}-\mathrm{N}$ and TKN in the leachate from Lysimeter 2

\section{Comparisons}

The onset of methanogenesis occurs within a similar period of time for both lysimeters, despite varying organic loadings. Both lysimeters showed no sign of acidic inhibition during the establishment of a methanogenic microflora. The rapid decrease in COD concentrations demonstrates the effectiveness of the methanogenic micro-organisms in the removal of the residual organic compounds. If acidic inhibition can be avoided, then the anaerobic microbial activity can be utilised as an effective biological treatment after landfilling. This would offer some degree of flexibility to account for areas in the windrows that are not properly aerated and thus require further treatment.

The stable methanogenic leachates from both lysimeters show similar COD and BOD levels. The concentration of nonbiodegradable COD is equal for both lysimeters. As the material for the lysimeters was from the same source, this suggests that these compounds would not have been affected during the aerobic treatment stage. A significant benefit of waste pretreatment is evident in the levels of ammoniacal nitrogen, which are substantially higher for the fresh waste than the pretreated waste.

The dependence of the DAT system on a significant proportion of woody waste (used for structural material) may detract from its suitability as it has been suggested that the slow degradation of these refractory organic materials may persist for decades (Robinson, 2000). The hypothesis that the long-term COD release is due to the breakdown of slowly degradable organic material such as wood and paper implies that these fractions should not be landfilled but rather subjected to further treatment.

\section{Implications for long-term pollution prediction}

The lysimeter results demonstrated the presence of a 'hard' or non-degradable COD, as described by Robinson et al. (2005).
The leachate is also characterised by slowly biodegradable organics. These compounds are likely to present a persistent pollution problem. The current DWAF discharge standards were used as criterion for acceptability of the leachate discharge in natural receptors (DWAF, 1998b). The refractory COD concentration at the end of the testing is calculated by subtracting the biodegradable content (BOD) from the total COD levels (Table 3). This parameter is assumed to be biologically nondegradable and therefore removed only by physical leaching. Similarly, as the biological consumption of $\mathrm{NH}_{4}-\mathrm{N}$ only occurs under aerobic conditions, its removal is also assumed to be reliant on physical processes. Further production of both refractory COD and ammoniacal nitrogen are assumed to be negligible. If the lysimeter is assumed to be a completely mixed reactor, the concentration of a pollutant (c) can be calculated after a given number of sampling cycles with Eq. (1), based on the Landsim Declining Source Term Model (Robinson, 2005b).

$$
c=c_{0} \exp \left(\frac{-V_{s}}{V_{t}} \theta\right)
$$

where:

$c$ is the pollutant concentration

$c_{0}$ is the initial concentration

$V_{s}$ is the volume of leachate removed for sampling (replaced by distilled water)

$V_{T}$ is the total lysimeter leachate volume

$\theta$ represents the number of sample cycles.

The number of sampling cycles is then used to determine the cumulative $\mathrm{L} / \mathrm{S}$ at that point. Based on the weekly removal of $2.5 \ell$ of leachate from the lysimeters, the $\mathrm{L} / \mathrm{S}$ ratio required in order to meet discharge standards and the projection of the $\mathrm{L} / \mathrm{S}$ ratio to a full scale landfill, as described above, are given in Table 3. The full-scale prediction is based on a $20 \mathrm{~m}$ deep landfill with an infiltration rate of $250 \mathrm{\ell} / \mathrm{m}^{2} \cdot \mathrm{a}$ and a dry density of $600 \mathrm{~kg} / \mathrm{m}^{3}$ (Leikam et al., 1997). It must be remembered that the accuracy of the predictions is limited due to the heterogenic nature of landfill sites and differences between the experimental set up and a full scale site such as leachate recirculation and rate of leachate release (Kylefors et al, 2003). The extrapolation of the $\mathrm{L} / \mathrm{S}$ ratio gives an idea of the timeframes that may be expected. Furthermore, landfills are assumed to be at field capacity, application of the approximations to sites in arid regions where leachate generation is sporadic is questionable although mathematically there is no distinction between continual flow or discreet leachate release, in the case of this particular model.

From the prediction of the time required to reach suitable discharge standards for the full-scale landfill the following comments can be made:

\begin{tabular}{|l|c|c|c|}
\hline \multicolumn{4}{|c|}{ TABLE 2 } \\
\multicolumn{4}{|l|}{ Characterisation of the input material to the lysimeters } \\
\hline Parameter & Unit & Fresh waste & 8 Weeks treated \\
\hline COD & & & \\
\hline Value at the end of trials & $\mathrm{mg} / \ell$ & 370 & 380 \\
\hline Discharge value (target) & $\mathrm{mg} / \ell$ & 75 & 75 \\
\hline Long-term L/S & & 2.8 & 2.4 \\
\hline Time required to reach target (Full-scale site) & years & 140 & 122 \\
\hline $\mathrm{NH}_{4}-\mathrm{N}$ & & & \\
\hline Value at the end of trials & $\mathrm{mg} / \ell$ & 75 & 16 \\
\hline Discharge value (target) & $\mathrm{mg} / \ell$ & 15 & 15 \\
\hline Long-term L/S & & 2.8 & 0.7 \\
\hline Time required to reach target (Full-scale site) & years & 141 & 29 \\
\hline
\end{tabular}


- The long-term COD release from landfills containing 8 weeks treated waste would be very similar to those containing untreated waste, as expected.

- The reduction of ammoniacal nitrogen levels in pretreated waste is significant after only 8 weeks of treatment.

The accelerated leaching out of pollutants may be possible by taking advantage of the high rainfall of the Durban area to increase the rate of liquid flux through the site to greater than $250 \mathrm{\ell} / \mathrm{m}^{2} \cdot \mathrm{a}$. Another consideration is of the target concentrations which may be unreasonably stringent and research is underway to assess the nature of leachates from treated waste and assess the suitability of the current discharge standards.

\section{Conclusion}

The benefits of pretreatment are realised in reduced levels of ammoniacal nitrogen in the leachates. However, the organic loading in the methanogenic leachate of treated waste remains unacceptably high. Unless studies show that the leachates from pretreated waste should be subject to less stringent discharge standards, MBT alone is not sufficient to result in the cessation of landfill aftercare (leachate treatment) within sustainable timeframes.

\section{Acknowledgments}

This research was part of a collaboration between the University of KwaZulu-Natal and the Technical University of Dresden (Germany) where the DAT was firstly developed. The authors would like to thank Prof. Norbert Mollekopf, Dr Joachim Brummack and Dr Silke Paar from TUD, and Prof. K Vorster from Tshwane University of Technology (South Africa) for their valuable technical assistance. This research was conducted with the financial and technical support of Durban Solid Waste.

\section{References}

ASTM (2004) American Standard Methods for the Examination of Water and WasteWater (20 ${ }^{\text {th }}$ edn.). American Water Works Association (AWWA).

BONE BD, KNOX K, PICKEN A and ROBINSON HD (2003) The effect of mechanical and biological pretreatment on landfill leachate quality. Conf. Proc. SARDINIA 2003, $9^{\text {th }}$ Int. Landfill Symp. Santa Margherita di Pula, Cagliari, Italy. October 2003.

COSSU R, RAGA R and ROSSETTI D (2003) The PAF model: An integrated approach for landfill sustainability. Waste Manage. 23 37-44.

DMWS Durban Metro Water Services (1998) Waste Stream Analysis Report. Document No. 1815/A0001. Durban Metro.

DWAF (1998a) Minimum Requirements for Waste Disposal by Landfill. Waste Management Series (2nd edn.). Department of Water Affairs and Forestry. South Africa

DWAF (1998b) Requirements for the Purification of Waste Water or Effluent: Special and General Standards. Department of Water Affairs and Forestry, South Africa. Government Gazette, 18 May 1984, No 9225 12-16.

HAUG RT (1993) The Practical Handbook of Compost Engineering. Lewis Publishers.
HÖRING K, KRUEMPELBECK I and EHRIG HJ (1999) Long term emission behaviour of mechanical-biological pretreated municipal solid waste. Conf. Proc. SARDINIA 99, $7^{\text {th }}$ Int. Landfill Symp. Santa Margherita di Pula, Cagliari, Italy. October 1999.

KYLEFORS K, ANDREAS L and LAGERKVIST A (2003) A comparison of small scale, pilot scale and large-scale tests for predicting leaching behaviour of landfilled wastes. Waste Manage. 23 45-49.

LEIKAM K and STEGMANN R (1997) Mechanical-biological pretreatment of residual municipal solid waste and the landfill behaviour of pretreated waste. Conf. Proc. SARDINIA 97, $6^{\text {th }}$ Int. Landfill Symp. Santa Margherita di Pula, Cagliari, Italy. October 1997.

MOLLEKOPF N, BRUMMACK J, PAAR S and VORSTER K (2002) Use of the dome aeration technology for biochemical stabilization of waste prior to landfilling. Conf. Proc. WASTECON 2002, Int. Waste Conf. and Expo. Durban, South Africa. 30 Sept - 4 Oct 2002.

MÜNNICH K, MAHLER CF and FRICKE K (2006) Pilot project of mechanical-biological treatment of waste in Brazil. Waste Manage. 26 150-157.

NOVELLA PH, EKAMA GA and BLIGHT GE (1997) Effects of liquid replacement strategies on waste stabilisation at pilot scale. Conf. Proc. SARDINIA 97, $6^{\text {th }}$ Int. Landfill Symp. Santa Margherita di Pula, Cagliari, Italy. October 1997.

NOVELLA PH, BALL JM, BLIGHT GE and STOW JG (2001) Coastal Park Landfill: 14 years of research. Conf. Proc. SARDINIA 2001, $8^{\text {th }}$ Int. Landfill Symp. Santa Margherita di Pula, Cagliari, Italy. October 2001.

PAAR S, BRUMMACK J and GEMENDE B (1999a) Mechanicalbiological waste stabilization by the dome aeration method. Environ. Prot. Eng. 25, Nr. 3/99.

PAAR S, BRUMMACK J and MOLLEKOPF N (1999b) The advantages of the DAT for the composting of solid waste. Conf. Proc. SARDINIA 99, $7^{\text {th }}$ Int. Landfill Symp. Santa Margherita di Pula, Cagliari, Italy. October 1999.

ROBINSON HD (1989) Development of methanogenic conditions within landfills. Conf. Proc. SARDINIA 89, 2nd Int. Landfill Symp. Santa Margherita di Pula, Cagliari, Italy. October 1989.

ROBINSON HD (2000) The future for landfills? A European perspective. Proc. Int. Training Seminar-Control, Management and Treatment of Landfill Emissions. University of Natal, Civil Engineering Programme, Durban, South Africa. December 2000.

ROBINSON HD, KNOX K, BONE BD and PICKEN A (2005a) Leachate quality from landfilled MBT waste. Waste Manage. 25 383-391.

ROBINSON HD, KNOX K and BONE BD (2005b) Improved Definition of Leachate Source Term from Landfills. Science Report P1-494/ SR1, Environment Agency, UK

SOYEZ K and PLICKERT S (2002) Mechanical-Biological treatment of waste (MBP) - Integration into waste management concepts. Conf. Proc. WASTECON 2002, Int. Waste Conf. and Expo. Durban, South Africa. 30 Sept -4 October 2002.

STEGMANN R (1982) Description of a Laboratory Scale Method to Investigate Anaerobic Degradation Processes Taking Place in Solid Waste. Conf. Proc. SARDINIA 97, $6^{\text {th }}$ Int. Landfill Symp. Santa Margherita di Pula, Cagliari, Italy. October 1997.

STEGMANN R (2005) Mechanical Biological Pretreatment of Municipal Solid Waste. Conf. Proc. SARDINIA 2005, 10 th Int. Landfill Symp. Santa Margherita di Pula, Cagliari, Italy. October 2005.

TROIS C, GRIFFITH M, MOLLEKOPF N and BRUMMACK J (2005) A comparative study of aerobic waste treatment: A solution for developing countries. Conf. Proc. SARDINIA 2005, $10^{\text {th }}$ Int. Landfill Symp. Santa Margherita di Pula, Cagliari, Italy. October 2005.

TROIS C and POLSTER A (2006) Effective pine bark composting with the dome aeration technology. Waste Manage. In Press, available on-line. 
Available on website http://www.wrc.org.za ISSN 0378-4738 = Water SA Vol. 32 No. 3 July 2006 ISSN 1816-7950 = Water SA (on-line) 